J. Dairy Sci. 96:4553-4567

http://dx.doi.org/10.3168/jds.2012-6480

(C) American Dairy Science Association ${ }^{\circledR}, 2013$.

\title{
Replacing alfalfa silage with corn silage in dairy cow diets: Effects on enteric methane production, ruminal fermentation, digestion, $\mathbf{N}$ balance, and milk production
}

\author{
F. Hassanat, ${ }^{*}$ R. Gervais, † C. Julien, ${ }^{* 1}$ D. I. Massé, ${ }^{*}$ A. Lettat, ${ }^{*}$ P. Y. Chouinard,† H. V. Petit, ${ }^{*}$ and C. Benchaar ${ }^{* 2}$ \\ ${ }^{*}$ Agriculture and Agri-Food Canada, Dairy and Swine Research and Development Centre, 2000 College Street, Sherbrooke, Quebec, \\ Canada J1M 0C8 \\ †Université Laval, Département des Sciences Animales, Québec, Québec, Canada G1V 0A6
}

\begin{abstract}
The objective of this study was to determine the effects of replacing alfalfa silage (AS) with corn silage (CS) in dairy cow total mixed rations (TMR) on enteric $\mathrm{CH}_{4}$ emissions, ruminal fermentation characteristics, apparent total-tract digestibility, $\mathrm{N}$ balance, and milk production. Nine ruminally cannulated lactating cows were used in a replicated $3 \times 3$ Latin square design (32-d period) and fed (ad libitum) a TMR [forage:concentrate ratio of 60:40; dry matter (DM) basis], with the forage portion consisting of either alfalfa silage (0\% CS; $56.4 \%$ AS in the TMR), a 50:50 mixture of both silages (50\% CS; $28.2 \%$ AS and $28.2 \%$ CS in the TMR), or corn silage (100\% CS; $56.4 \%$ CS in the TMR). Increasing the CS proportion (i.e., at the expense of AS) in the diet was achieved by decreasing the corn grain proportion and increasing that of soybean meal. Intake of DM and milk yield increased quadratically, whereas DM digestibility increased linearly as the proportion of CS increased in the diet. Increasing the dietary CS proportion resulted in changes (i.e., lower ruminal $\mathrm{pH}$ and acetate:propionate ratio, reduced fiber digestibility, decreased protozoa numbers, and lower milk fat and higher milk protein contents) typical of those observed when cows are fed high-starch diets. A quadratic response in daily $\mathrm{CH}_{4}$ emissions was observed in response to increasing the proportion of CS in the diet (440, 483, and $434 \mathrm{~g} / \mathrm{d}$ for $0 \% \mathrm{CS}, 50 \% \mathrm{CS}$, and $100 \% \mathrm{CS}$, respectively). Methane production adjusted for intake of DM, and gross or digestible energy was unaffected in cows fed the $50 \%$ CS diet, but decreased in cows fed the $100 \%$ CS diet (i.e., quadratic effect). Increasing the CS proportion in the diet at the expense of AS improved $\mathrm{N}$ utilization, as reflected by the decreases in ruminal

Received December 13, 2012.

Accepted April 2, 2013.

${ }^{1}$ Visiting scientist from UMR INRA-INPT Tissus Animaux Nutrition Digestion Ecosystème et Métabolisme, F-31326 Castanet Tolosan, France.

${ }^{2}$ Corresponding author: chaouki.benchaar@agr.gc.ca
\end{abstract}

$\mathrm{NH}_{3}$ concentration and manure $\mathrm{N}$ excretion, suggesting low potential $\mathrm{NH}_{3}$ and $\mathrm{N}_{2} \mathrm{O}$ emissions. Results from this study, suggest that total replacement of AS with CS in dairy cow diets offers a means of decreasing $\mathrm{CH}_{4}$ output and $\mathrm{N}$ losses. However, the reduction in fiber degradation and the resulting increase in volatile solids content of the manure may lead to increased $\mathrm{CH}_{4}$ emissions from manure storage.

Key words: corn silage, alfalfa silage, enteric methane, $\mathrm{N}$ balance

\section{INTRODUCTION}

Environmental concerns over greenhouse gas (GHG) emissions from global anthropogenic activities are growing. In 2010, agricultural GHG emissions represented $6.3 \%$ (428 million $\mathrm{t}$ of $\mathrm{CO}_{2}$ equivalent) and $8 \%$ (56 million $\mathrm{t}$ of $\mathrm{CO}_{2}$ equivalent) of the total emissions in the United States (EPA, 2012) and Canada (Environment Canada, 2012), respectively. These emissions are 11 and 19\% above the values reported in 1990 for the United States and Canada, respectively. According to these reports, enteric fermentation contributes up to $33 \%$ (mostly in the form of $\mathrm{CH}_{4}$ ), whereas manure management contributes 12 to $16 \%$ (mostly in the form of $\mathrm{N}_{2} \mathrm{O}$ and $\mathrm{CH}_{4}$ ) of agricultural GHG emissions. Enteric $\mathrm{CH}_{4}$ production represents a loss in productive energy for the animal. Typically, $\mathrm{CH}_{4}$ energy losses from ruminants represent between 2 and $12 \%$ of gross energy (GE) intake, and between 3.9 to $7.4 \%$ for the dairy cow (Kebreab et al., 2008), depending on the level of feed intake and the composition of the diet (Benchaar et al., 2001; Boadi et al., 2004; Beauchemin et al., 2009). Accordingly, several dietary strategies are being proposed to mitigate enteric $\mathrm{CH}_{4}$ emissions from ruminants.

Forages represent the major source of ingredients in dairy cow diets. Despite their importance (nutritionally and economically), very few studies have investigated the effect of forage type on enteric $\mathrm{CH}_{4}$ emissions. Compared with legume and grass silages, corn silage (CS) contains higher amounts of starch, which make 
it an interesting means to reduce enteric $\mathrm{CH}_{4}$ production from dairy cows. It is well established that feeding more starch to ruminants reduces enteric $\mathrm{CH}_{4}$ energy losses (Benchaar et al., 2001; Beauchemin et al., 2009). Fermentation of starch lowers ruminal $\mathrm{pH}$ and favors the production of propionate at the expense of acetate in the rumen, which can result in a decrease in $\mathrm{CH}_{4}$ production, given the inverse relationship between propionate formation and ruminal methanogenesis. Feeding high-starch diets may result in a decrease in protozoa numbers, which reduces hydrogen transfer from protozoa to methanogens, thereby contributing to reducing $\mathrm{CH}_{4}$ production and inhibition of methanogen growth (Wolin and Miller, 1988; Hegarty, 1999).

To the best of our knowledge, no studies have been performed to directly quantify the extent to which enteric $\mathrm{CH}_{4}$ emissions can be reduced by feeding CS instead of legume silage to dairy cows. We hypothesized that replacing alfalfa silage (AS) with CS in the diet would increase dietary starch supply and make the ruminal environment (i.e., lower ruminal $\mathrm{pH}$ and acetate:propionate ratio) less favorable to methanogenesis, which would result in lower $\mathrm{CH}_{4}$ energy losses in dairy cows. Hence, the objective of this study was to determine the effects of replacing $\mathrm{AS}$ with $\mathrm{CS}$ in dairy cow diets on feed intake, enteric $\mathrm{CH}_{4}$ production, ruminal fermentation, digestion, $\mathrm{N}$ balance, milk production, and milk composition.

\section{MATERIALS AND METHODS}

This study was conducted at the Dairy and Swine Research and Development Centre, Sherbrooke, Quebec, Canada. Animal procedures were conducted under the approval of the Institutional Animal Care Com- mittee of the Dairy and Swine Research and Development Center (Sherbrooke, QC, Canada) and were in accordance with the guidelines of the Canadian Council on Animal Care (Ottawa, ON, Canada; CCAC, 1993).

\section{Cows, Experimental Design, and Diets}

Nine multiparous lactating Holstein cows fitted with ruminal cannulas $(10 \mathrm{~cm}$; Bar Diamond Inc., Parma, ID) were used in a replicated $3 \times 3$ Latin square design (32-d period). The cows averaged $82 \pm 18$ DIM at the start of the experiment, with an average BW of $688 \pm$ $66 \mathrm{~kg}$ and milk yield of $41 \pm 4 \mathrm{~kg} / \mathrm{d}$. The experimental treatments were based on increasing the proportion of CS in the TMR (60:40 forage:concentrate ratio, DM basis) at the expense of AS. The chemical composition and the ensiling characteristics of the 2 silages are presented in Table 1 . The dietary treatments were (1) 0\% CS (56.4\% AS in the TMR), (2) 50\% CS (28.2\% AS and $28.2 \%$ CS in the TMR), and (3) $100 \%$ CS (56\% CS in the TMR). Each diet (Table 2) was provided for ad libitum intake ( $5 \%$ orts, on an as-fed basis) and cows were housed in individual tie-stalls and had free access to water during the experiment.

After 2 wk of adaptation to experimental diets, feed intake, in sacco ruminal degradability, ruminal fermentation characteristics, apparent total-tract digestibility, $\mathrm{N}$ balance, milk production, milk composition, and $\mathrm{CH}_{4}$ production were measured. Only 2 air flow-controlled chambers were available for measuring $\mathrm{CH}_{4}$ emissions in this study, which limited the number of animals that could be examined at the same time to 2 (i.e., 1 cow per chamber). Consequently, $\mathrm{CH}_{4}$ determination had to be staggered by $4 \mathrm{~d}$ to facilitate measurements for all the cows. Cows were weighed at the beginning and the

Table 1. Chemical composition of alfalfa silage and corn silage

\begin{tabular}{lcc}
\hline & \multicolumn{2}{c}{ Experimental silage } \\
\cline { 2 - 3 } Item & Alfalfa silage & Corn silage \\
\hline Chemical composition & & \\
OM (\% of DM) & 91.0 & 96.3 \\
CP (\% of DM) & 20.4 & 6.80 \\
NDF (\% of DM) & 35.7 & 33.3 \\
ADF (\% of DM) & 32.5 & 20.1 \\
Starch (\% of DM) & 1.81 & 33.9 \\
Ether extract (\% of DM) & 6.87 & 4.56 \\
Gross energy (Mcal/kg of DM) & 4.25 & 4.20 \\
Ensiling characteristics & & 3.70 \\
pH & 4.22 & 3.86 \\
Lactic acid (\% of DM) & 7.42 & 1.43 \\
Acetic acid (\% of DM) & 2.61 & 0.14 \\
Propionic acid (\% of DM) & 0.24 & 0.20 \\
Butyric acid (\% of DM) & 0.09 & 1.01 \\
Ammonia (\% of DM) & 2.77 & 0.35 \\
Ethanol (\% of DM) & 0.22 & 1.75 \\
Water-soluble carbohydrates (\% of DM) & 1.83 \\
\hline
\end{tabular}


Table 2. Ingredient and chemical composition of experimental diets with increasing proportions of corn silage (CS)

\begin{tabular}{|c|c|c|c|}
\hline \multirow[b]{2}{*}{ Item } & \multicolumn{3}{|c|}{ Treatment } \\
\hline & $0 \% \mathrm{CS}$ & $50 \% \mathrm{CS}$ & $100 \% \mathrm{CS}$ \\
\hline \multicolumn{4}{|l|}{ Ingredient ( $\%$ of DM) } \\
\hline Alfalfa silage & 56.4 & 28.2 & 0.0 \\
\hline Corn silage & 0.0 & 28.2 & 56.4 \\
\hline Corn grain, ground & 25.5 & 19.2 & 12.4 \\
\hline Soybean meal & 2.2 & 9.2 & 16.2 \\
\hline Soybean hulls & 5.9 & 5.8 & 5.8 \\
\hline Timothy hay & 3.2 & 3.2 & 3.2 \\
\hline Corn gluten feed & 2.1 & 2.6 & 3.0 \\
\hline Rumen inert fat ${ }^{1}$ & 2.0 & 1.0 & 0.0 \\
\hline Urea & 0.0 & 0.1 & 0.2 \\
\hline Calcium carbonate & 0.5 & 0.4 & 0.6 \\
\hline Potassium carbonate & 0.0 & 0.0 & 0.4 \\
\hline Mineral and vitamin supplement ${ }^{2}$ & 2.3 & 2.4 & 1.8 \\
\hline \multicolumn{4}{|l|}{ Chemical composition } \\
\hline $\mathrm{OM}(\%$ of $\mathrm{DM})$ & 91.7 & 92.8 & 94.2 \\
\hline $\mathrm{CP}(\%$ of $\mathrm{DM})$ & 16.8 & 16.2 & 15.6 \\
\hline NDF (\% of DM) & 30.7 & 29.7 & 28.6 \\
\hline $\mathrm{ADF}(\%$ of $\mathrm{DM})$ & 23.4 & 20.2 & 17.0 \\
\hline Starch (\% of DM) & 17.0 & 22.8 & 30.0 \\
\hline Ether extract (\% of DM) & 7.02 & 5.48 & 3.40 \\
\hline $\mathrm{NFC}^{3}(\%$ of DM) & 37.2 & 41.4 & 47.0 \\
\hline Gross energy (Mcal/kg of DM) & 4.55 & 4.49 & 4.39 \\
\hline
\end{tabular}

${ }^{1}$ Energy Booster 100 (Milk Specialties Global Animal Nutrition, Carpentersville, IL).

${ }^{2}$ Contained $12.48 \% \mathrm{Ca}, 6.80 \% \mathrm{P}, 6.81 \% \mathrm{~S}, 7.72 \% \mathrm{Na}, 1.97 \% \mathrm{~K}, 96 \mathrm{mg}$ of I $/ \mathrm{kg}, 2,877 \mathrm{mg}$ of Fe $/ \mathrm{kg}, 620 \mathrm{mg}$ of $\mathrm{Cu} / \mathrm{kg}, 2,520 \mathrm{mg}$ of $\mathrm{Mn} / \mathrm{kg}, 3,777 \mathrm{mg}$ of $\mathrm{Zn} / \mathrm{kg}, 83 \mathrm{mg}$ of $\mathrm{Co} / \mathrm{kg}, 628000 \mathrm{IU}$ of vitamin $\mathrm{A} / \mathrm{kg}, 81,000 \mathrm{IU}$ of vitamin $\mathrm{D} / \mathrm{kg}, 3,739 \mathrm{IU}$ of vitamin $\mathrm{E} / \mathrm{kg}$, and $27.8 \mathrm{mg}$ of $\mathrm{Se} / \mathrm{kg}$.

${ }^{3} \mathrm{NFC}=\mathrm{OM}-(\mathrm{CP}+\mathrm{NDF}+$ ether extract $)$.

end of each experimental period on 2 consecutive days before the a.m. feeding and after the a.m. milking.

\section{Feed Intake, Apparent Total-Tract Digestibility, and N Balance}

Apparent total-tract digestibility and $\mathrm{N}$ outputs were measured over 7 consecutive days. Diets were offered in equal amounts twice daily (0900 and $1930 \mathrm{~h}$ ). Feed consumption was recorded daily by weighing feeds offered to and refused by the cows. Samples of the TMR, feed ingredients, and orts were collected daily and stored at $-20^{\circ} \mathrm{C}$. Samples were composited by cow within period, freeze dried, ground to pass a 1-mm screen using a Wiley mill (standard model 4; Arthur M. Thomas Co., Philadelphia, PA) and analyzed for DM, OM, total $\mathrm{N}$, NDF, ADF, starch, ether extract (EE), and GE. Samples of AS and CS were also analyzed for ethanol, lactic acid, VFA, ammonia N, and water-soluble carbohydrates.

Total collection of feces and urine was performed by fitting cows with harnesses and tubes, allowing the collection of feces and urine separately. Feces were weighed and mixed daily, and a representative sample $(2 \%)$ was collected, stored at $-20^{\circ} \mathrm{C}$, and subsequently thawed, freeze dried, and ground to pass a 1-mm screen using a Wiley mill for later analysis of OM, total N, NDF, $\mathrm{ADF}$, starch, EE, and GE. Total urine was collected daily into reinforced plastic containers containing an appropriate amount of sulfuric acid $(50 \% \mathrm{vol} / \mathrm{vol})$ to maintain $\mathrm{pH}<2.0$. A representative sample $(2 \%)$ was collected and kept frozen at $-20^{\circ} \mathrm{C}$ until analyzed for total $\mathrm{N}$. Retained $\mathrm{N}$ was calculated by subtracting $\mathrm{N}$ in feces, urine, and milk from $\mathrm{N}$ intake. Productive $\mathrm{N}$ was calculated as the sum of $\mathrm{N}$ retained in the body and $\mathrm{N}$ secreted in milk.

\section{In Sacco Ruminal Degradability}

Ruminal degradability of AS and CS was determined in 2 Latin squares using a nylon bag procedure. Feeds were freeze dried and ground to pass a $1-\mathrm{mm}$ screen using a Wiley mill and 5-g samples (DM) were weighed in triplicate in polyester bags $(17 \mathrm{~cm} \times 9 \mathrm{~cm} ; 53-\mu \mathrm{m}$ pore size) made of monofilament PeCap polyester (Sefar Nitex; Sefar AG, Heiden, Switzerland). Bags were placed in a large mesh $(46 \mathrm{~cm} \times 38 \mathrm{~cm} ; 3-\times 5-\mathrm{mm}$ pores) retaining sac containing a 700-g anchor to keep the bags immersed in the rumen while allowing the ruminal fluid to circulate freely. Bags were soaked in $37^{\circ} \mathrm{C}$ water for $5 \mathrm{~min}$ before being placed in the ventral sac of the rumen for $2,4,8,16,24,48,72$, and $96 \mathrm{~h}$. 
Upon removal from the rumen, bags were immediately immersed in ice water to impede microbial activity, and then thoroughly rinsed with cold tap water and frozen at $-20^{\circ} \mathrm{C}$. Bags were later thawed, washed in a domestic washing machine, and dried for $48 \mathrm{~h}$ at $55^{\circ} \mathrm{C}$. Bags and contents were weighed and dried residues were ground through a 1-mm screen (1093 Cyclotec sample mill; Foss Analytical AB, Höganäs, Sweden) and stored for subsequent determination of DM and OM. Bags used for time- 0 disappearance were soaked in water at $37^{\circ} \mathrm{C}$ for $5 \mathrm{~min}$ and then treated similarly to the other bags.

Kinetics of ruminal degradation of OM of AS and CS were calculated using a nonlinear model (McDonald, 1981). The PROC NLIN of SAS (SAS Institute Inc., Cary, NC) was used to fit the following model:

$$
\begin{gathered}
\mathrm{P}=\mathrm{a}+\mathrm{b}\left(1-\mathrm{e}^{-\mathrm{c}(\mathrm{t}-\mathrm{L})}\right) \text { for } t>\mathrm{L}, \\
\mathrm{P}=\mathrm{a} \text { for } \mathrm{t} \leq \mathrm{L},
\end{gathered}
$$

where $\mathrm{P}=$ percentage of $\mathrm{OM}$ disappearance from the nylon bag at time $\mathrm{t}, \mathrm{a}=$ soluble and rapidly degradable fraction $(\%), \mathrm{b}=$ slowly degradable fraction $(\%), \mathrm{c}=$ fractional rate of disappearance of the fraction $b(/ h)$, $\mathrm{L}=$ lag time $(\mathrm{h})$, and $\mathrm{t}=$ time of incubation $(\mathrm{h})$. The model was fitted using $(a+b) \leq 100, b \geq 0, c \geq 0$, and $\mathrm{L} \geq 0$ constraints.

The effective ruminal degradability (ERD) of OM was calculated using the equation

$$
\mathrm{ERD}=\mathrm{a}+[\mathrm{bc} /(\mathrm{c}+\mathrm{kp})] \times \mathrm{e}^{(-\mathrm{kpL})},
$$

where $\mathrm{kp}$ is the ruminal fractional passage rate, calculated at $0.05 / \mathrm{h}$ from the equations suggested by the NRC (2001) for wet forages.

\section{Ruminal Fermentation Characteristics and Protozoa Enumeration}

Ruminal fluid was collected from cows on 2 successive days before $(0 \mathrm{~h})$ and at $1,2,4,6$, and $8 \mathrm{~h}$ after the a.m. feeding. A total of $250 \mathrm{~mL}$ was collected from the anterior dorsal, anterior ventral, medium ventral, posterior dorsal, and posterior ventral locations within the rumen using a $50-\mathrm{mL}$ syringe screwed to a stainless tube ending with a probe covered by a fine metal mesh (RT Rumen Fluid Sampler Tube; Bar Diamond Inc.). Ruminal fluid was acidified to $\mathrm{pH} 2$ with $50 \% \mathrm{H}_{2} \mathrm{SO}_{4}$ and subsamples $(15 \mathrm{~mL})$ were frozen at $-20^{\circ} \mathrm{C}$ for later determination of VFA and $\mathrm{NH}_{3}$ concentrations.

Ruminal $\mathrm{pH}$ was measured continuously for $48 \mathrm{~h}$ using a Kahne bolus system (KB1000; Kahne Ltd., Auckland, New Zealand). The system was composed of Kahne bolus probes and a wireless receiver $(433 \mathrm{MHz})$ connected to a computer and operated by Kahne System V5.2.3 software (Kahne Ltd.), as described in Kaur et al. (2010). Kahne bolus probes were calibrated to $\mathrm{pH}$ 4.00 and 7.00 at $40^{\circ} \mathrm{C}$ and then set to measure the $\mathrm{pH}$ every minute. The probes were then attached to a 0.5 $\mathrm{kg}$ metal weight to ensure that it was always immersed in the ruminal fluid, and then placed in the ventral sac. After $48 \mathrm{~h}$, the probes were removed, washed, and data were downloaded. The probes were then immersed in $\mathrm{pH} 4.00$ and $\mathrm{pH} 7.00$ buffers kept at $40^{\circ} \mathrm{C}$, and the probe drift did not exceed \pm 0.05 . The $\mathrm{pH}$ data were summarized as mean $\mathrm{pH}$, minimum $\mathrm{pH}$, maximum $\mathrm{pH}$, time spent below $\mathrm{pH} 6.0$, time spent below $\mathrm{pH} 5.6$, time spent below $\mathrm{pH} 5.2$, area $($ time $\times \mathrm{pH})$ when $5.6<\mathrm{pH}$ $<6.0$, area when $5.2<\mathrm{pH}<5.6$, and area when $\mathrm{pH}$ was $<5.2$ over $24 \mathrm{~h}$ (Plaizier et al., 2001; Keunen et al., 2002; Khafipour et al., 2009b).

Protozoa enumeration was carried out on ruminal content collected before $(0 \mathrm{~h})$ and $4 \mathrm{~h}$ after the a.m. feeding. Ruminal content $(\sim 1 \mathrm{~L})$ was strained through 4 layers of cheesecloth and a 5 -mL portion of the strained ruminal fluid was preserved using $5 \mathrm{~mL}$ of methyl green formalin-saline solution for protozoa enumeration (Ogimoto and Imai, 1981). Protozoa samples were stored at room temperature in darkness until counting. Protozoa were microscopically enumerated using a counting chamber (Neubauer Improved Bright-Line counting cell, 0.1-mm depth; Hausser Scientific Co., Horsham, PA) and genera were identified as outlined by Dehority (1993). Each sample was counted twice, and if the average of the duplicates differed by more than $10 \%$, the counts were repeated.

\section{Milk Production and Milk Composition}

Cows were milked twice daily at 0700 and $1900 \mathrm{~h}$ in their stalls and milk production was recorded at each milking. During digestibility measurements, milk samples were collected from each cow at each milking, stored at $+4^{\circ} \mathrm{C}$ with a preservative (2-bromo-2-nitropropan-1,3-diol), and then sent to a commercial laboratory (Valacta Dairy Production Center of Expertise QuebecAtlantic, Sainte-Anne-de-Bellevue, QC, Canada) for analyses of fat, protein, lactose, MUN, and SCC.

\section{Methane Production}

Two air-flow controlled chambers were used for measurement of $\mathrm{CH}_{4}$ production. The chambers measured $4.09-\mathrm{m}$ length $\times 2.95-\mathrm{m}$ width $\times 2.84-\mathrm{m}$ height. When the chamber doors were closed, air entered the chamber through a ventilation duct and exited through an exhaust. The air temperature within the chamber was maintained at $18 \pm 1^{\circ} \mathrm{C}$. Air flow into and out of the 
chamber was measured using inline mass flowmeters (FT2; Fox Thermal Instruments Inc., Marina, CA) and maintained at $180 \pm 10 \mathrm{~m}^{3} / \mathrm{h}$. Methane concentration was continuously measured at the air entrance and exhaust ducts using $\mathrm{CH}_{4}$ analyzers (MGA3000; ADC Gas Analysis Ltd., Hoddesdon, Hertfordshire, UK). The amount of $\mathrm{CH}_{4}$ (entering and leaving the chamber) was calculated by multiplying the concentration of $\mathrm{CH}_{4}$ by the airflow (at entrance and at exhaust). The difference between the incoming and outgoing mass of $\mathrm{CH}_{4}$ corresponded to the amount of enteric $\mathrm{CH}_{4}$ emitted in each chamber by the animal. The chambers were calibrated before the experiment by releasing known amounts of $\mathrm{CH}_{4}$ in each chamber (with no cow inside) and calculating the recovered amounts from the difference incoming and ingoing $\mathrm{CH}_{4}$. The recovered amounts ranged from 98 to $102 \%$. The calibration factors (i.e., to adjust each chamber to $100 \%$ recovery) were used to correct $\mathrm{CH}_{4}$ emissions data. A small positive pressure was generated inside each chamber to prevent inflow of gases into the chambers. Cows were preconditioned to the environmental chambers before the beginning of the experiment. To reduce the effect of isolation on animal behavior, the chambers were equipped with windows and speakers so the cow in the chamber can see and hear other cows. Cows entered the chambers $18 \mathrm{~h}$ before starting $\mathrm{CH}_{4}$ measurements. Methane was recorded every minute over a period of 3 consecutive days and fluxes were averaged to derive 24-h $\mathrm{CH}_{4}$ emissions. Within each chamber, the cow was kept in a tie-stall that measured $1.82 \mathrm{~m}$ long $\times 1.60 \mathrm{~m}$ wide, elevated from the floor by $25 \mathrm{~cm}$. Manure was collected from each cow in a stainless box placed below and to the rear of each stall. Farm personnel accessed the chambers twice daily (0800 and $2000 \mathrm{~h}$ ) to feed and milk the cows and remove the manure. The doors were kept opened for a maximum of 1 to $1.5 \mathrm{~min}$ to allow exchange of material in and out of the chambers. This resulted in interruptions of flux measurements for 15 to $30 \mathrm{~min}$ : the time required for gas concentrations to reach steady state. These interruptions had little effect on daily emissions because fluxes were calculated every minute and averaged to derive the 24 -h period emissions values. Cows in the chambers had free access to water and were fed twice daily for ad libitum intake ( $5 \%$ orts on an as-fed basis). Offered feed and orts were weighed daily to determine feed consumption. Samples of feed offered and orts were collected, pooled, and kept frozen for later determination of DM and GE concentrations.

\section{Chemical Analyses}

Dry matter was determined by oven drying at $55^{\circ} \mathrm{C}$ for $48 \mathrm{~h}$. Analytical DM was determined by drying in a vacuum oven at $100^{\circ} \mathrm{C}$ overnight (AOAC, 1990; method 934.01). Ash content was determined by incineration at $550^{\circ} \mathrm{C}$ overnight in a muffle furnace (AOAC, 1990; method 942.05) and the OM content was calculated as the difference between 100 and the percentage of ash. Crude protein $(\mathrm{N} \times 6.25)$ was determined using the macro-Kjeldahl procedure (AOAC, 1990; method 990.03). The concentration of NDF was determined as described by Van Soest et al. (1991) without the use of sodium sulfite and with the inclusion of heatstable $\alpha$-amylase. The ADF content was determined according to the method of the Association of Official Analytical Chemists (AOAC, 1990; method 973.18). The NDF and ADF procedures were adapted for use in an $\mathrm{ANKOM}^{200}$ fiber analyzer (Ankom Technology Corp., Fairport, NY). The concentration of starch was determined colorimetrically according to the procedure of Hall et al. (2001). Ether extract was determined using the Soxtec 2047 SoxCap in combination with Soxtec extraction systems (Foss, Eden Prairie, MN) according to the method of AOAC (1990; method 920.39). Gross energy was determined using an oxygen bomb calorimeter (model 6200; Parr Instrument Co., Moline, IL). The concentration of $\mathrm{N}$ in acidified urine samples was determined by micro-Kjeldahl analysis (AOAC, 1990). Silage extracts were analyzed for water-soluble carbohydrates (DuBois et al., 1956), lactic acid (Taylor, 1996), and for ethanol using GLC (model 6850; Agilent Technologies Canada Inc., Mississauga, ON, Canada).

Volatile FA were analyzed using an HPLC (Series 1200; Agilent Technologies Canada Inc.). The HPLC was equipped with a refractive index detector and Aminex HPX-87H column $(300 \times 7.8 \mathrm{~mm})$ packed with sulfonated divinyl benzene-styrene copolymer [Bio-Rad Laboratories (Canada) Ltd., Mississauga, ON, Canada]. The mobile phase was $0.005 M$ sulfuric acid and the flow rate was $0.6 \mathrm{~mL} / \mathrm{min}$. Ammonia $\mathrm{N}$ concentration was determined as in Weatherburn (1967). Protein, fat, lactose, urea N, and SCC in milk samples were analyzed by infrared spectroscopy (MilkoScan FT 6000; Foss Electric A/S, Hillerød, Denmark). Milk composition was corrected for differences in milk yield between a.m. and p.m. milkings.

\section{Statistical Analyses}

Data were analyzed using PROC MIXED of SAS (SAS Institute Inc.). The statistical model included treatment and period as fixed effects and square and cow within square as random effects. Ruminal fermentation characteristics ( $\mathrm{pH}, \mathrm{VFA}, \mathrm{NH}_{3}$, and protozoa) data were analyzed as repeated measures using the same model, with the addition of the fixed effects of day, sampling time (i.e., hour), and all interactions. The $\mathrm{CH}_{4}$ data were also 
analyzed as repeated measures with the inclusion of the fixed effects of day and day $x$ treatment interaction. The fixed effect of the chamber was initially included in the model but was removed because it was not significant. The first-order autoregressive $[\mathrm{AR}(1)]$ was used as the covariance structure and cow within treatment $\times$ period as subject for the repeated measures. In sacco ruminal degradability data were analyzed as a $3 \times 3$ duplicated Latin square design and the model included the fixed effects of treatment and period, and the random effect of square and cows within square. Orthogonal polynomial contrasts (linear and quadratic) were used to examine treatment effect on response variables. Significant effect of treatment on least squares means was declared when $P \leq 0.05$, whereas tendencies were declared when 0.05 $<P \leq 0.10$.

\section{RESULTS}

\section{Silage and Diet Composition}

Alfalfa was harvested at the late vegetative to early bud stage, whereas corn was harvested at 0.50 to 0.67 milk line stage (38\% DM). Alfalfa silage contained more CP (20.4 vs. $6.8 \%)$ and NDF (35.7 vs. $33.3 \%$ ) but less starch (1.8 vs. $33.9 \%$ ) than CS, on a DM basis (Table 1). To balance the experimental diets, the corn grain proportion was decreased, whereas the soybean meal proportion was increased as the proportion of CS increased and that of AS decreased in the diet (Table 2).
Consequently, as CS proportion in the diet increased, the starch concentration increased, whereas concentrations of NDF and ADF decreased. A minor decrease in $\mathrm{CP}(-1.2$ percentage units $)$ and $\mathrm{GE}(-0.16 \mathrm{Mcal} /$ $\mathrm{kg}$ of $\mathrm{DM}$ ) concentrations was observed when the diet was formulated to contain only CS (i.e., $100 \%$ CS treatment) compared with the diet containing only AS (i.e., 0\% CS treatment).

\section{Intake and Digestibility}

Increasing the proportion of CS and soybean meal (i.e., decreasing AS and corn grain proportions) in the diet resulted in a quadratic effect on DM and OM intakes (Table 3). Intakes of NDF and CP averaged 6.63 and $3.65 \mathrm{~kg} / \mathrm{d}$, respectively, and were not affected by treatment, whereas ADF intake declined linearly $(P<$ $0.01)$ as the dietary proportion of CS increased. Starch intake increased linearly $(P<0.01)$ as the proportion of CS in the diet increased. Gross energy intake was affected in a quadratic manner $(P=0.04)$, being highest when cows were offered the $50 \%$ CS diet and lowest at when cows were fed the $0 \%$ CS diet.

Apparent total-tract digestibility of DM, OM, GE, and CP increased linearly $(P \leq 0.03)$, whereas that of NDF and ADF decreased linearly $(P<0.01)$ as the CS proportion in the diet increased. Digestibility of starch remained unaffected $(P=0.55)$, whereas that of $\mathrm{EE}$ responded quadratically $(P<0.01)$ to increasing the proportion of CS in the diet.

Table 3. Intake and total-tract digestibility of nutrients in lactating dairy cows fed increasing proportions of corn silage (CS) in the diet

\begin{tabular}{|c|c|c|c|c|c|c|}
\hline \multirow[b]{2}{*}{ Item } & \multicolumn{3}{|c|}{ Treatment $^{1}$} & \multirow[b]{2}{*}{ SEM } & \multicolumn{2}{|c|}{$P$-value } \\
\hline & $0 \% \mathrm{CS}$ & $50 \% \mathrm{CS}$ & $100 \% \mathrm{CS}$ & & Linear & Quadratic \\
\hline \multicolumn{7}{|l|}{ Intake } \\
\hline \multicolumn{7}{|l|}{ DM } \\
\hline $\mathrm{kg} / \mathrm{d}$ & 21.7 & 23.0 & 22.8 & 0.69 & 0.02 & 0.05 \\
\hline$\%$ of BW & 3.14 & 3.30 & 3.24 & 0.178 & 0.09 & 0.04 \\
\hline $\mathrm{OM}(\mathrm{kg} / \mathrm{d})$ & 19.9 & 21.4 & 21.5 & 0.67 & $<0.01$ & 0.05 \\
\hline $\mathrm{CP}(\mathrm{kg} / \mathrm{d})$ & 3.65 & 3.73 & 3.58 & 0.111 & 0.52 & 0.18 \\
\hline NDF $(\mathrm{kg} / \mathrm{d})$ & 6.64 & 6.81 & 6.43 & 0.196 & 0.31 & 0.15 \\
\hline $\mathrm{ADF}(\mathrm{kg} / \mathrm{d})$ & 5.06 & 4.64 & 3.84 & 0.150 & $<0.01$ & 0.20 \\
\hline Starch $(\mathrm{kg} / \mathrm{d})$ & 3.68 & 5.25 & 6.86 & 0.168 & $<0.01$ & 0.83 \\
\hline Ether extract $(\mathrm{kg} / \mathrm{d})$ & 1.51 & 1.27 & 0.78 & 0.057 & $<0.01$ & $<0.01$ \\
\hline Gross energy (Mcal/d) & 98.5 & 103.4 & 100.2 & 3.12 & 0.41 & 0.04 \\
\hline \multicolumn{7}{|l|}{ Apparent digestibility (\%) } \\
\hline $\mathrm{DM}$ & 69.7 & 70.6 & 71.3 & 0.57 & 0.03 & 0.91 \\
\hline $\mathrm{OM}$ & 71.0 & 71.9 & 72.9 & 0.59 & 0.02 & 0.91 \\
\hline $\mathrm{CP}$ & 68.7 & 69.3 & 71.7 & 0.97 & $<0.01$ & 0.27 \\
\hline $\mathrm{NDF}$ & 55.4 & 51.8 & 47.3 & 1.35 & $<0.01$ & 0.76 \\
\hline $\mathrm{ADF}$ & 56.2 & 52.5 & 44.7 & 1.97 & $<0.01$ & 0.29 \\
\hline Starch & 98.4 & 98.4 & 98.2 & 0.27 & 0.55 & 0.74 \\
\hline Ether extract & 54.7 & 58.2 & 47.2 & 1.97 & 0.01 & $<0.01$ \\
\hline Gross energy & 67.7 & 69.1 & 70.5 & 0.53 & $<0.01$ & 0.99 \\
\hline
\end{tabular}

${ }^{1}$ The diet (60:40 forage:concentrate ratio; DM basis) contained $0,28.2$, or $56.4 \%$ CS (DM basis). 


\section{Ruminal In Sacco Degradability}

In sacco ruminal OM degradation parameters and ERD of the 2 silages are presented in Table 4. The slowly degradable fraction (b) of AS increased $(P=$ $0.04)$, whereas a numerical decline $(P=0.11)$ was observed for the fractional degradation rate (c) as the CS proportion (and soybean meal) in the diet increased at the expense of AS (and corn grain). These changes caused a linear decrease $(P=0.02)$ in ERD of AS as the dietary proportion of CS increased. No significant changes were observed in degradation kinetic parameters and ERD of CS when cows were fed diets with increasing amounts of CS. Overall, ERD of CS was 9 percentage units higher than that of AS.

\section{Ruminal Fermentation Characteristics}

Because the interactions between day and treatment were not significant for any of the ruminal fermentation parameters, only averages of the 2-d measurements were reported. Mean ruminal $\mathrm{pH}$ declined linearly $(P$ $<0.01$ ) as the proportion of CS (and soybean meal) increased in the diet (at the expense of AS and corn grain). A similar response was observed for minimum $\mathrm{pH}$ values, whereas maximum $\mathrm{pH}$ values were not affected by treatment (Table 5). Daily duration (min) of ruminal $\mathrm{pH}<6.0$ increased quadratically $(P=0.04)$, whereas that of $\mathrm{pH}<5.6$ increased linearly $(P \leq 0.02)$ as the proportion of CS in the diet increased. Linear effects $(P<0.01)$ of treatment were observed for area $5.6<\mathrm{pH}<6.0$ and area $5.2<\mathrm{pH}<5.6$. The duration or area of $\mathrm{pH}<5.2$ was negligible and was not affected by treatment.
Except for valerate molar proportion $(P=0.32)$, the treatment $\times$ sampling time interaction was significant $(P \leq 0.05)$ for the molar proportions of the other VFA, total VFA, and $\mathrm{NH}_{3}$ concentrations (Table 6). These interactions were due to changes in the magnitude of differences between treatments at each sampling time, as illustrated for acetate proportion (Figure 1), propionate proportion (Figure 2), and $\mathrm{NH}_{3}$ concentration (Figure 3).

Total VFA concentration averaged $102.4 \mathrm{~m} M$ and was unaffected by increasing the proportion of CS in the diet. Molar proportion of acetate decreased linearly $(P<0.01)$ and that of propionate increased linearly $(P$ $<0.01)$ as the amount of CS increased in the diet. As a consequence, the acetate:propionate ratio decreased linearly $(P<0.01)$ with increasing dietary CS proportions. A quadratic decrease $(P=0.01)$ was observed for butyrate molar proportion. Increasing the CS proportion in the diet caused linear decreases $(P \leq 0.01)$ in $\mathrm{NH}_{3}$ concentration and branched-chain VFA (sum of isobutyrate and isovalerate) molar proportion. Total protozoa and entodiniomorph (i.e., 99\% of total protozoa count) populations decreased linearly $(P<0.01)$, whereas holotrich populations increased quadratically as the proportion of CS in the diet increased.

\section{Milk Production and Milk Composition}

Milk and ECM yields responded quadratically $(P \leq$ 0.05 ) to increasing the proportion of CS (and soybean meal) at the expense of AS (and corn grain) in the diet (Table 7). Yield of FCM was not significantly affected by increasing the proportion of CS in the diet, although it was numerically lowest for cows fed the $100 \%$ CS diet

Table 4. In sacco OM degradation kinetic parameters and effective degradability of alfalfa and corn silages in lactating dairy cows fed increasing proportions of corn silage (CS) in the diet

\begin{tabular}{|c|c|c|c|c|c|c|}
\hline \multirow[b]{2}{*}{ Item $^{1}$} & \multicolumn{3}{|c|}{ Treatment $^{2}$} & \multirow[b]{2}{*}{ SEM } & \multicolumn{2}{|c|}{$P$-value } \\
\hline & $0 \% \mathrm{CS}$ & $50 \% \mathrm{CS}$ & $100 \% \mathrm{CS}$ & & Linear & Quadratic \\
\hline \multicolumn{7}{|l|}{ Alfalfa silage } \\
\hline $\mathrm{a}(\%)$ & 43.9 & 43.5 & 43.4 & 0.24 & 0.09 & 0.60 \\
\hline $\mathrm{b}(\%)$ & 30.8 & 32.5 & 33.6 & 0.79 & 0.04 & 0.74 \\
\hline $\mathrm{c}(/ \mathrm{h})$ & 0.055 & 0.042 & 0.040 & 0.0062 & 0.11 & 0.50 \\
\hline Lag time $(\mathrm{h})$ & 1.58 & 1.84 & 3.17 & 0.862 & 0.23 & 0.63 \\
\hline $\operatorname{ERD}(\%)$ & 58.4 & 56.6 & 55.6 & 0.72 & 0.02 & 0.67 \\
\hline \multicolumn{7}{|l|}{ Corn silage } \\
\hline $\mathrm{a}(\%)$ & 59.4 & 59.7 & 59.8 & 0.97 & 0.63 & 0.90 \\
\hline b (\%) & 28.6 & 33.1 & 30.2 & 2.81 & 0.70 & 0.31 \\
\hline $\mathrm{c}(/ \mathrm{h})$ & 0.020 & 0.016 & 0.017 & 0.0032 & 0.48 & 0.58 \\
\hline Lag time $(\mathrm{h})$ & 5.51 & 4.05 & 4.38 & 1.850 & 0.51 & 0.54 \\
\hline $\operatorname{ERD}(\%)$ & 65.4 & 65.5 & 65.5 & 1.17 & 0.90 & 1.00 \\
\hline
\end{tabular}

${ }^{1} \mathrm{a}=$ soluble and rapidly degradable fraction; $\mathrm{b}=$ slowly degradable fraction; $\mathrm{c}=$ fractional rate of disappearance of the fraction $\mathrm{b} ; \mathrm{ERD}=$ effective ruminal degradability.

${ }^{2}$ The diet (60:40 forage:concentrate ratio; DM basis) contained 0, 28.2, or 56.4\% CS (DM basis). 
Table 5. Ruminal pH parameters of lactating dairy cows fed increasing proportions of corn silage (CS) in the diet

\begin{tabular}{|c|c|c|c|c|c|c|}
\hline \multirow[b]{2}{*}{ Item } & \multicolumn{3}{|c|}{ Treatment $^{1}$} & \multirow[b]{2}{*}{ SEM } & \multicolumn{2}{|c|}{$P$-value } \\
\hline & $0 \% \mathrm{CS}$ & $50 \% \mathrm{CS}$ & $100 \% \mathrm{CS}$ & & Linear & Quadratic \\
\hline \multicolumn{7}{|l|}{$\mathrm{pH}$} \\
\hline Mean & 6.31 & 6.27 & 6.07 & 0.031 & $<0.01$ & 0.07 \\
\hline Minimum & 5.85 & 5.82 & 5.54 & 0.052 & $<0.01$ & 0.08 \\
\hline Maximum & 6.68 & 6.69 & 6.62 & 0.046 & 0.39 & 0.53 \\
\hline Time $\mathrm{pH}<6.0(\min )$ & 89 & 179 & 558 & 51.1 & $<0.01$ & 0.04 \\
\hline Time $\mathrm{pH}<5.6(\min )$ & 2 & 2 & 68 & 18.2 & 0.02 & 0.17 \\
\hline Time $\mathrm{pH}<5.2(\min )$ & 0 & 0 & 9 & 5.4 & 0.24 & 0.49 \\
\hline Area $5.6<\mathrm{pH}<6.0(\mathrm{pH} \times \min / \mathrm{d})$ & 434 & 854 & 2,297 & 246.2 & $<0.01$ & 0.11 \\
\hline Area $5.2<\mathrm{pH}<5.6(\mathrm{pH} \times \min / \mathrm{d})$ & 8 & 11 & 245 & 55.8 & $<0.01$ & 0.11 \\
\hline Area $\mathrm{pH}<5.2(\mathrm{pH} \times \min / \mathrm{d})$ & 0 & 0 & 37 & 21.5 & 0.24 & 0.49 \\
\hline
\end{tabular}

${ }^{1}$ The diet (60:40 forage:concentrate ratio; DM basis) contained $0,28.2$, or $56.4 \%$ CS (DM basis).

(quadratic effect, $P=0.11)$. Milk fat percentage $(P<$ $0.01)$ and milk fat yield $(P=0.02)$ decreased linearly, whereas milk protein content and milk protein yield increased linearly $(P<0.01)$ with increasing CS dietary proportions. The concentration of MUN responded quadratically $(P<0.01)$ to increasing the proportion of $\mathrm{CS}$ in the diet. Feed efficiency expressed as kilograms of FCM produced per kilogram of DMI decreased linearly $(P=0.01)$ as the proportion of CS increased in the diet. The decrease tended to be linear $(P=0.08)$ when feed efficiency was expressed as kilograms of ECM produced per kilogram of DMI.

\section{Methane Production}

No interactions were observed between day and treatment for $\mathrm{CH}_{4}$ measurements and, therefore, only averages over the 3 - $\mathrm{d}$ measurements were reported
(Table 8). Increasing CS and soybean meal proportions (i.e., decreasing AS and corn grain proportions) in the diet resulted in a linear increase in DMI during the 3-d measurement of $\mathrm{CH}_{4}$ emissions. Enteric $\mathrm{CH}_{4}$ production [expressed as $\mathrm{g} / \mathrm{d}, \mathrm{g} / \mathrm{kg}$ of DMI, \% of GE intake, or \% of digestible energy (DE) intake] responded quadratically $(P \leq 0.01)$ to increasing inclusion of CS. When expressed on a milk yield basis, $\mathrm{CH}_{4}$ production decreased linearly $(P=0.04)$ with increasing proportions of $\mathrm{CS}$ in the diet. The response in $\mathrm{CH}_{4}$ production was quadratic $(P<0.01)$ when emissions were expressed on an FCM or ECM basis. Feeding cows increasing amounts of $\mathrm{CS}$ caused a quadratic increase $(P<0.01)$ in $\mathrm{CH}_{4}$ when emissions were related to the amount of milk fat produced. When expressed on the basis of kilograms of milk protein produced, $\mathrm{CH}_{4}$ production decreased linearly $(P<0.01)$ as the proportion of CS increased in the diet.

Table 6. Total VFA concentration, VFA molar proportions, $\mathrm{NH}_{3}$ concentration, and protozoa numbers in ruminal fluid of lactating dairy cows fed increasing proportions of corn silage (CS) in the diet

\begin{tabular}{|c|c|c|c|c|c|c|}
\hline \multirow[b]{2}{*}{ Item } & \multicolumn{3}{|c|}{ Treatment $^{1}$} & \multirow[b]{2}{*}{ SEM } & \multicolumn{2}{|c|}{$P$-value } \\
\hline & $0 \% \mathrm{CS}$ & $50 \% \mathrm{CS}$ & $100 \% \mathrm{CS}$ & & Linear & Quadratic \\
\hline \multirow{2}{*}{\multicolumn{7}{|c|}{ VFA (mol/100 mol) }} \\
\hline & & & & & & \\
\hline Acetate $(\mathrm{A})$ & 64.0 & 62.3 & 59.0 & 1.22 & $<0.01$ & 0.18 \\
\hline Propionate $(\mathrm{P})$ & 19.9 & 21.4 & 26.4 & 1.45 & $<0.01$ & 0.06 \\
\hline Butyrate & 11.5 & 12.0 & 10.4 & 0.35 & 0.02 & 0.01 \\
\hline Valerate & 1.56 & 1.53 & 1.61 & 0.105 & 0.52 & 0.39 \\
\hline Branched-chain $\mathrm{VFA}^{2}$ & 3.02 & 2.76 & 2.57 & 0.194 & 0.01 & 0.80 \\
\hline $\mathrm{A}: \mathrm{P}$ ratio & 3.24 & 3.01 & 2.41 & 0.217 & $<0.01$ & 0.13 \\
\hline $\mathrm{NH}_{3}(\mathrm{~m} M)$ & 10.44 & 8.29 & 6.79 & 0.787 & $<0.01$ & 0.61 \\
\hline \multicolumn{7}{|l|}{ Protozoa } \\
\hline Total $\left(\times 10^{5} / \mathrm{mL}\right)$ & 4.85 & 4.75 & 3.35 & 0.618 & $<0.01$ & 0.07 \\
\hline Entodiniomorphs $\left(\times 10^{5} / \mathrm{mL}\right)$ & 4.83 & 4.68 & 3.29 & 0.611 & $<0.01$ & 0.08 \\
\hline Holotrichs $^{3}\left(\times 10^{3} / \mathrm{mL}\right)$ & 1.94 & 4.03 & 3.80 & 0.800 & $<0.01$ & 0.04 \\
\hline
\end{tabular}

${ }^{1}$ The diet (60:40 forage:concentrate ratio; DM basis) contained 0, 28.2, or 56.4\% CS (DM basis).

${ }^{2}$ Branched-chain VFA $=$ isobutyrate + isovalerate.

${ }^{3}$ Holotrichs $=$ Isotricha + Dasytricha . 


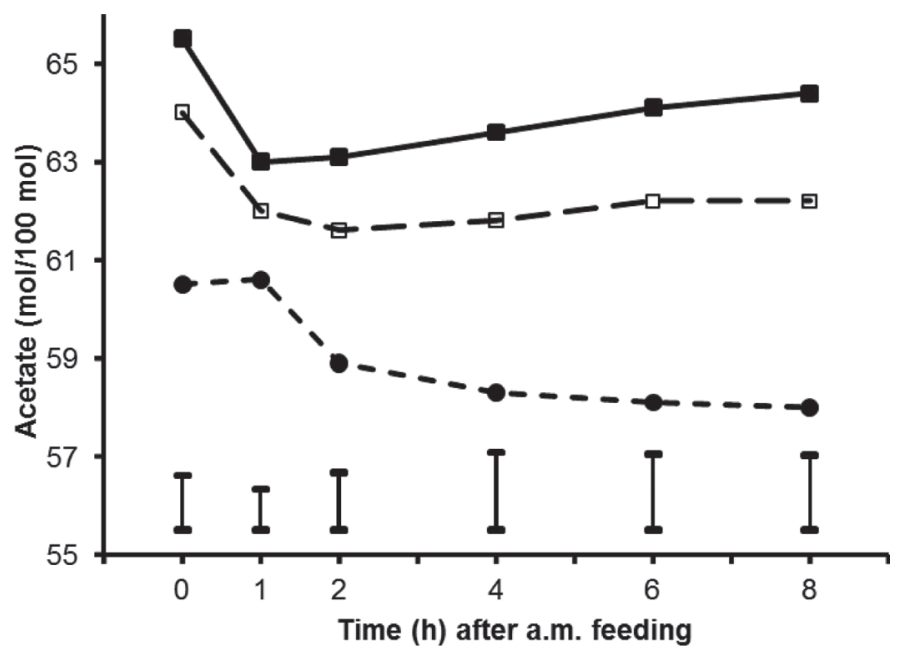

Figure 1. Ruminal acetate proportion in lactating dairy cows fed increasing proportions of corn silage (CS) in the diet ( $0 \%$ CS; $\square 50 \%$ CS; $100 \%$ CS). The diet (60:40 forage:concentrate ratio, DM basis) contained 0, 28.2, or $56.4 \%$ CS (DM basis).

\section{N Balance}

Nitrogen intake averaged $584 \pm 18 \mathrm{~g} / \mathrm{d}$ and was not affected by treatment (Table 9). Increasing the proportions of CS and soybean meal (i.e., decreasing the proportions of AS and corn grain) in the diet caused a quadratic decrease $(P<0.01)$ in the amount $(\mathrm{g} / \mathrm{d})$ of $\mathrm{N}$ excreted in feces. This decrease was linear $(P<0.01)$ when fecal $\mathrm{N}$ was expressed as a proportion of $\mathrm{N}$ intake. Urinary $\mathrm{N}$ (g/d or \% of $\mathrm{N}$ intake) decreased quadratically $(P=0.01)$ with increasing proportions of CS in the diet. Total manure $\mathrm{N}$ excretion decreased linearly

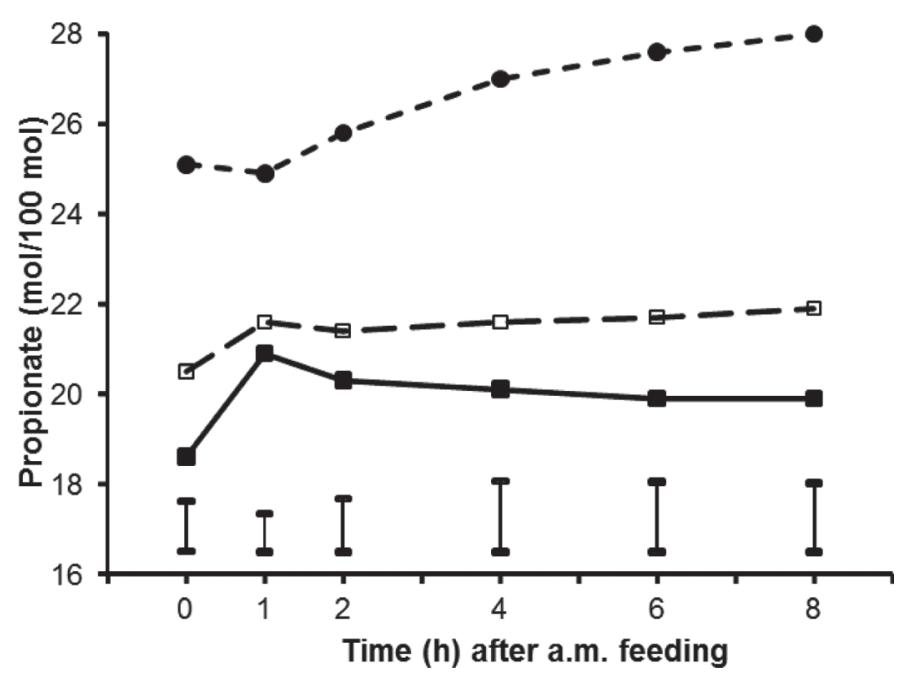

Figure 2. Ruminal propionate proportion in lactating dairy cows fed increasing proportions of corn silage (CS) in the diet ( $0 \%$ CS; $\square 50 \% \mathrm{CS} ; 100 \% \mathrm{CS})$. The diet (60:40 forage:concentrate ratio, DM basis) contained $0,28.2$, or $56.4 \%$ CS (DM basis).

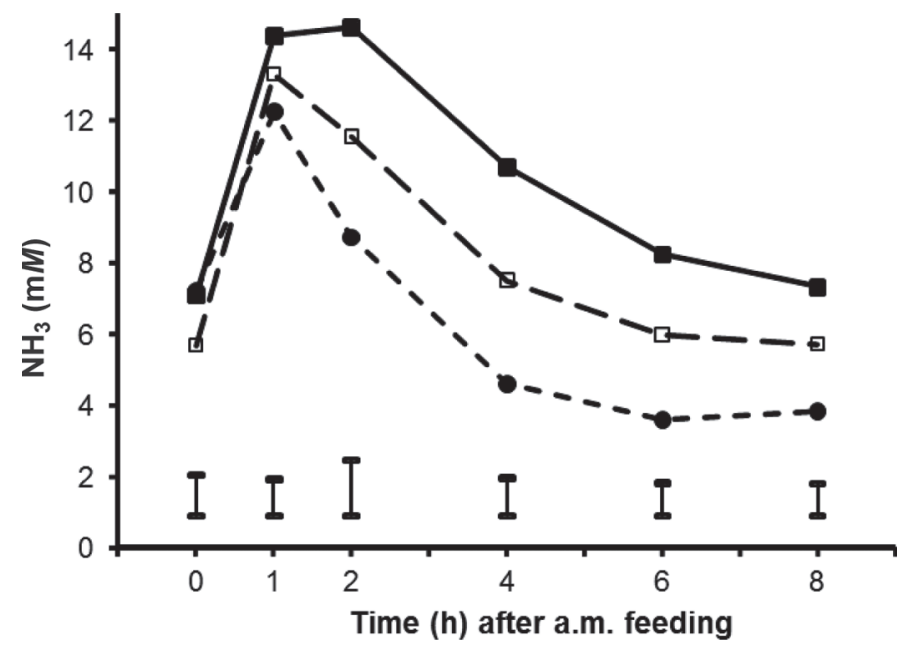

Figure 3. Ruminal $\mathrm{NH}_{3}$ concentration in lactating dairy cows fed increasing proportions of corn silage (CS) in the diet ( $0 \%$ CS; $\square 50 \%$ CS; 100\% CS). The diet (60:40 forage:concentrate ratio, DM basis) contained $0 \%, 28.2 \%$ or $56.4 \%$ CS (DM basis).

$(P<0.01)$ with increasing dietary CS proportion. Efficiency of $\mathrm{N}$ use $(\mathrm{N}$ in milk/ $\mathrm{N}$ intake) increased linearly when cows were fed diets with increasing amounts of CS. Retained $\mathrm{N}$ was not affected by treatment, whereas productive $\mathrm{N}$ increased linearly $(P \leq 0.04)$ as the proportion of CS increased in the diet.

\section{DISCUSSION}

\section{Effects of Corn Silage on Enteric $\mathrm{CH}_{4}$}

In the current study, $\mathrm{CH}_{4}$ energy losses (\% of $\mathrm{GE}$ intake) averaged $5.72 \%$ (ranging from 5.27 to $6.05 \%$ ), which is very close to the average value of $5.70 \%$ (varying from 5.23 to $6.09 \%$ ) determined in a previous study from our laboratory (Benchaar et al., 2013). This average value of $5.72 \%$ is within the range (i.e., 5.5 to $7.5 \%$ ) of the default $\mathrm{CH}_{4}$ conversion rate of $6.5 \pm 1 \%$ suggested by the Intergovernmental Panel on Climate Change Tier 2 methodology (IPCC, 2006) and used by different countries to calculate inventories of enteric $\mathrm{CH}_{4}$ emissions from dairy sectors.

In this study, we examined the effect of altering dietary forage source on enteric $\mathrm{CH}_{4}$ emissions of dairy cows by replacing AS (and corn grain) with CS (and soybean meal). We anticipated that the high starch content of CS would favor the production of propionate at the expense of acetate in the rumen, which could result in a decrease in $\mathrm{CH}_{4}$ production, given the inverse relationship between propionate formation and $\mathrm{CH}_{4}$ production in the rumen.

Cows fed $0 \%$ CS ingested $21.7 \mathrm{~kg}$ of $\mathrm{DM} / \mathrm{d}$ and emitted daily $440 \mathrm{~g}$ of $\mathrm{CH}_{4}$. When expressed in grams per 
Table 7. Milk production and milk composition of lactating dairy cows fed increasing proportions of corn silage $(\mathrm{CS})$ in the diet

\begin{tabular}{|c|c|c|c|c|c|c|}
\hline \multirow[b]{2}{*}{ Item } & \multicolumn{3}{|c|}{ Treatment $^{1}$} & \multirow[b]{2}{*}{ SEM } & \multicolumn{2}{|c|}{$P$-value } \\
\hline & $0 \% \mathrm{CS}$ & $50 \% \mathrm{CS}$ & $100 \% \mathrm{CS}$ & & Linear & Quadratic \\
\hline \multicolumn{7}{|l|}{ Production $(\mathrm{kg} / \mathrm{d})$} \\
\hline Milk & 32.3 & 35.3 & 34.3 & 3.64 & 0.01 & $<0.01$ \\
\hline $\mathrm{FCM}^{2}$ & 31.6 & 32.2 & 30.2 & 3.01 & 0.14 & 0.11 \\
\hline $\mathrm{ECM}^{3}$ & 33.7 & 35.1 & 33.4 & 3.27 & 0.74 & 0.05 \\
\hline \multicolumn{7}{|l|}{ Component (\%) } \\
\hline Fat & 3.88 & 3.47 & 3.26 & 0.162 & $<0.01$ & 0.43 \\
\hline Protein & 3.04 & 3.16 & 3.22 & 0.060 & $<0.01$ & 0.68 \\
\hline Lactose & 4.57 & 4.52 & 4.52 & 0.061 & 0.43 & 0.60 \\
\hline $\mathrm{SCC}\left(\times 10^{3} / \mathrm{mL}\right)$ & 58 & 84 & 75 & 1.3 & 0.45 & 0.40 \\
\hline $\operatorname{MUN}(\mathrm{mg} / \mathrm{dL})$ & 13.8 & 11.8 & 13.4 & 0.65 & 0.58 & $<0.01$ \\
\hline \multicolumn{7}{|l|}{ Yield $(\mathrm{kg} / \mathrm{d})$} \\
\hline Fat & 1.24 & 1.21 & 1.10 & 0.106 & 0.02 & 0.44 \\
\hline Protein & 0.98 & 1.11 & 1.10 & 0.105 & $<0.01$ & 0.01 \\
\hline Lactose & 1.48 & 1.60 & 1.56 & 0.179 & 0.05 & 0.02 \\
\hline \multicolumn{7}{|l|}{ Feed efficiency } \\
\hline Milk/DMI & 1.48 & 1.53 & 1.51 & 0.121 & 0.46 & 0.28 \\
\hline FCM/DMI & 1.45 & 1.40 & 1.33 & 0.096 & 0.01 & 0.80 \\
\hline $\mathrm{ECM} / \mathrm{DMI}$ & 1.55 & 1.53 & 1.47 & 0.103 & 0.08 & 0.64 \\
\hline
\end{tabular}

${ }^{1}$ The diet (60:40 forage:concentrate ratio; DM basis) contained 0, 28.2, or $56.4 \% \mathrm{C}$ (DM basis).

${ }^{2} 4 \% \mathrm{FCM}=0.4 \times$ milk yield $(\mathrm{kg} / \mathrm{d})+15 \times$ fat yield $(\mathrm{kg} / \mathrm{d})$ (Tyrrell and Reid, 1965).

${ }^{3}$ Energy-corrected milk $=0.327 \times$ milk yield $(\mathrm{kg} / \mathrm{d})+12.95 \times$ fat yield $(\mathrm{kg} / \mathrm{d})+7.2 \times$ protein yield $(\mathrm{kg} / \mathrm{d})$ (Tyrrell and Reid, 1965).

day, $\mathrm{CH}_{4}$ production increased in cows fed the $50 \% \mathrm{CS}$ diet. This increase can be related to increased DMI $(+1.6 \mathrm{~kg} / \mathrm{d})$ because $\mathrm{CH}_{4}$ production is proportional to DMI (Benchaar et al., 2001; Boadi et al., 2004). However, cows fed $100 \%$ CS diet did not respond similarly to those fed the $50 \% \mathrm{CS}$ diet, as $\mathrm{CH}_{4}$ production remained unchanged despite an increase $(+2.9 \mathrm{~kg} / \mathrm{d})$ in DMI. When corrected for intake of DM, GE, or DE, the cows' response to increased CS proportion was also quadratic, as $\mathrm{CH}_{4}$ production was not changed by feeding cows the $50 \%$ CS diet, whereas it decreased when cows were offered the $100 \%$ CS diet. Thus, in the present study, increasing starch content of the diet (via increasing dietary CS proportion) from 17 (i.e., $0 \% \mathrm{CS}$ ) to $23 \%$ (i.e., $50 \%$ CS) did not have sufficient impact on the ruminal environment (i.e., ruminal $\mathrm{pH}$, acetate:propionate ratio, and protozoal populations). In contrast, feeding a diet containing $30 \%$ starch (i.e.,

Table 8. Methane production of lactating dairy cows fed increasing proportions of corn silage (CS) in the diet

\begin{tabular}{|c|c|c|c|c|c|c|}
\hline \multirow[b]{2}{*}{ Item } & \multicolumn{3}{|c|}{ Treatment $^{1}$} & \multirow[b]{2}{*}{ SEM } & \multicolumn{2}{|c|}{$P$-value } \\
\hline & $0 \% \mathrm{CS}$ & $50 \% \mathrm{CS}$ & $100 \% \mathrm{CS}$ & & Linear & Quadratic \\
\hline$\overline{\mathrm{DMI}^{2}(\mathrm{~kg} / \mathrm{d})}$ & 21.7 & 23.3 & 24.6 & 0.44 & $<0.01$ & 0.70 \\
\hline $\mathrm{CH}_{4}$ & & & & & & \\
\hline $\mathrm{g} / \mathrm{d}$ & 440 & 483 & 434 & 22.9 & 0.71 & $<0.01$ \\
\hline $\mathrm{g} / \mathrm{kg}$ of DMI & 20.3 & 20.7 & 17.7 & 0.82 & $<0.01$ & $<0.01$ \\
\hline$\%$ of GE intake ${ }^{3}$ & 5.85 & 6.05 & 5.27 & 0.244 & $<0.01$ & $<0.01$ \\
\hline$\%$ of $\mathrm{DE}^{4}$ & 8.65 & 8.76 & 7.47 & 0.355 & $<0.01$ & 0.01 \\
\hline $\mathrm{g} / \mathrm{kg}$ of milk ${ }^{5}$ & 14.2 & 14.2 & 13.4 & 2.05 & 0.04 & 0.21 \\
\hline $\mathrm{g} / \mathrm{kg}$ of $\mathrm{FCM}^{5}$ & 14.3 & 15.3 & 14.6 & 1.78 & 0.36 & $<0.01$ \\
\hline $\mathrm{g} / \mathrm{kg}$ of $\mathrm{ECM}^{5}$ & $\begin{array}{l}14.0 \\
13.4\end{array}$ & $\begin{array}{l}10.0 \\
14.0\end{array}$ & $\begin{array}{l}14.0 \\
13.2\end{array}$ & $\begin{array}{l}1.10 \\
1.67\end{array}$ & $\begin{array}{l}0.00 \\
0.43\end{array}$ & $<0.01$ \\
\hline $\mathrm{g} / \mathrm{kg}$ of milk fat $^{5}$ & 361 & 404 & 397 & 40.2 & $<0.01$ & $<0.01$ \\
\hline $\mathrm{g} / \mathrm{kg}$ of milk protein ${ }^{5}$ & 466 & 447 & 415 & 60.3 & $<0.01$ & 0.52 \\
\hline
\end{tabular}

${ }^{1}$ The diet (60:40 forage:concentrate ratio; DM basis) contained 0, 28.2, or $56.4 \%$ CS (DM basis).

${ }^{2}$ Determined for 3 consecutive days during which cows were in the chambers.

${ }^{3} \mathrm{GE}=$ gross energy.

${ }^{4} \mathrm{DE}=$ digestible energy (estimated from energy digestibility measured over the 7-d collection period).

${ }^{5}$ Yields of milk, FCM, ECM, milk fat, and milk protein measured for 7 consecutive days (i.e., performance measurements). 
Table 9. Nitrogen balance in lactating dairy cows fed increasing proportions of corn silage (CS) in the diet

\begin{tabular}{|c|c|c|c|c|c|c|}
\hline \multirow[b]{2}{*}{ Item } & \multicolumn{3}{|c|}{ Treatment $^{1}$} & \multirow[b]{2}{*}{ SEM } & \multicolumn{2}{|c|}{$P$-value } \\
\hline & $0 \% \mathrm{C}$ & $50 \% \mathrm{CS}$ & $100 \% \mathrm{CS}$ & & Linear & Quadratic \\
\hline Intake N (g/d) & 583 & 597 & 573 & 17.7 & 0.52 & 0.18 \\
\hline \multicolumn{7}{|l|}{ Fecal N } \\
\hline $\mathrm{g} / \mathrm{d}$ & 176 & 180 & 158 & 4.69 & $<0.01$ & $<0.01$ \\
\hline$\%$ of $\mathrm{N}$ intake & 31.3 & 30.7 & 28.3 & 0.97 & $<0.01$ & 0.27 \\
\hline \multicolumn{7}{|l|}{ Urinary N } \\
\hline $\mathrm{g} / \mathrm{d}$ & 216 & 185 & 188 & 8.6 & $<0.01$ & 0.01 \\
\hline$\%$ of $\mathrm{N}$ intake & 37.4 & 31.2 & 33.2 & 2.05 & 0.03 & 0.01 \\
\hline \multicolumn{7}{|l|}{ Total N excretion } \\
\hline $\mathrm{g} / \mathrm{d}$ & 387 & 369 & 351 & 13.4 & $<0.01$ & 1.00 \\
\hline$\%$ of $\mathrm{N}$ intake & 68.7 & 62.0 & 61.5 & 2.87 & $<0.01$ & 0.13 \\
\hline \multicolumn{7}{|l|}{ Milk N } \\
\hline $\mathrm{g} / \mathrm{d}$ & 153 & 173 & 175 & 16.5 & $<0.01$ & 0.03 \\
\hline$\%$ of $\mathrm{N}$ intake & 26.1 & 29.1 & 30.5 & 2.20 & $<0.01$ & 0.32 \\
\hline \multicolumn{7}{|l|}{ Retained N } \\
\hline $\mathrm{g} / \mathrm{d}$ & 32.9 & 54.5 & 47.9 & 12.10 & 0.39 & 0.36 \\
\hline$\%$ of $\mathrm{N}$ intake & 5.19 & 8.95 & 8.07 & 1.967 & 0.32 & 0.35 \\
\hline \multicolumn{7}{|l|}{ Productive $\mathrm{N}^{2}$} \\
\hline $\mathrm{g} / \mathrm{d}$ & 186 & 228 & 223 & 20.9 & 0.04 & 0.11 \\
\hline$\%$ of $\mathrm{N}$ intake & 31.3 & 38.0 & 38.5 & 2.87 & $<0.01$ & 0.13 \\
\hline
\end{tabular}

${ }^{1}$ The diet (60:40 forage:concentrate ratio; DM basis) contained 0\%, 28.2, or 56.4\% CS (DM basis).

${ }^{2}$ Retained $\mathrm{N}+\mathrm{N}$ in milk.

$100 \%$ CS treatment) caused substantial changes in the ruminal environment, which resulted in a reduction in $\mathrm{CH}_{4}$ production (g/d; \% of GE, or DE intake). Such quadratic responses suggest that a critical dietary concentration of starch is required to make the ruminal environment less favorable for methanogenesis. A similar quadratic response in daily $\mathrm{CH}_{4}$ output $(\mathrm{g} / \mathrm{d})$ was also observed by Mc Geough et al. (2010) in beef cattle fed whole-crop wheat silages with increasing grain content (i.e., increasing concentrations of starch).

In this study, the increase in starch intake when cows were fed the $100 \%$ CS diet is considered as the main factor that induced changes in the ruminal environment, digestibility, and hence, $\mathrm{CH}_{4}$ production. In vitro work showed that fermentation of starch produced less $\mathrm{CH}_{4}$ per gram of fermented OM compared with sucrose, fructans, hemicellulose, and pectin, or nonlignified fiber (Hindrichsen et al., 2004). Aguerre et al. (2011) reduced the dietary starch content and increased the fiber concentration by increasing the proportion of forage in dairy cow diets and reported an increase in $\mathrm{CH}_{4}$ (expressed as grams per day per kilogram of DMI or per kilogram of milk yield).

Feeding cows the $100 \%$ CS diet led to an acidic ruminal environment ( $\mathrm{pH}$ averaging $6.07 ; 9 \mathrm{~h} / \mathrm{d}$ at $\mathrm{pH}$ $<6.0)$ and shifted the VFA pattern toward proportionally more propionate and less acetate and butyrate. Several studies reported a lower acetate proportion and acetate:propionate ratio, and (or) a higher propionate proportion when CS replaced AS in dairy cow diets (Ruppert et al., 2003; Brito and Broderick, 2006;
Benchaar et al., 2007), which agrees with our findings. Ruminal fermentation of starch produces more propionate than fermentation of other carbohydrates (Fahey and Berger, 1988). Additionally, a low ruminal $\mathrm{pH}$ favors a low acetate:propionate ratio (Van Soest, 1994; Lana et al., 1998; Cerrato-Sánchez et al., 2008). Production of acetate and butyrate liberates hydrogen, whereas propionate serves as a net hydrogen sink. As a consequence, diets that increase propionate and decrease acetate in the rumen are often associated with a reduction in ruminal methanogenesis, given that less hydrogen is available to methanogens for reducing $\mathrm{CO}_{2}$ to $\mathrm{CH}_{4}$.

In the present study, the decrease in acetate proportion in the rumen of cows fed the $100 \%$ CS diet can be related to the decrease in ruminal NDF degradation, as revealed by the reduced in sacco ERD of AS and the associated decreased in NDF digestibility. Fibrolytic activity in the rumen is very often impaired by fermentable carbohydrates, probably due to the negative associative effects of starch and fiber digestion. It is recognized that the growth of cellulolytic bacteria and fiber digestion are compromised at $\mathrm{pH} 6.0$ to 5.8 (Mould and Ørskov, 1983; Hoover, 1986), which was visible when cows consumed the $100 \%$ CS treatment.

The decrease in methanogenesis observed in cows fed the $100 \%$ CS diet could also be attributed to the effect of treatment on rumen protozoal populations. The decreased protozoa numbers in these cows was consistent with the lower butyrate molar proportion, as protozoa are butyrate producers (Brossard et al., 
2004; Morgavi et al., 2012). The symbiotic relationship between methanogens and protozoa is well established (Finlay et al., 1994; Newbold et al., 1995; McAllister and Newbold, 2008). Archaea methanogens present inside and on the surface of protozoa utilize hydrogen produced by protozoa during nutrient fermentation for $\mathrm{CH}_{4}$ synthesis. Fonty et al. (1995) suggested that a low ruminal $\mathrm{pH}$ coupled with a high propionate concentration would be a toxic environment for protozoa, and a decrease in their population has been reported when these conditions occurred in the rumen, as observed in our study and other studies as well (Hristov et al., 2001; Khafipour et al., 2009a,b,c). Other studies, however, reported no changes or an increase in protozoa numbers in ruminants fed high-starch diets. For instance, Franzolin and Dehority (1996) reported an increase in protozoa numbers in ruminal fluid of steers fed increasing proportions of concentrate. More recently, Hook et al. (2011) observed greater ruminal protozoa numbers in dairy cows fed a high-concentrate diet compared with cows fed a high-forage diet. Discrepancy between studies in protozoa response to dietary starch increases could be due to a shift within individual protozoal populations. Franzolin and Dehority (1996) suggested that variations could be also a result of the type of protozoa present in the rumen, with different genera showing varying sensitivities to ruminal $\mathrm{pH}$ (i.e., starch addition).

Changes in milk yield and milk protein content (i.e., increases) and in milk fat concentration (i.e., decrease) are typical of those observed when dairy cows are fed starch-rich diets. As a consequence of these changes in milk yield and milk components, the amount of $\mathrm{CH}_{4}$ per kilogram of milk produced decreased in cows fed the $100 \%$ CS treatment. The quadratic effect on FCM and ECM yield due to increasing the CS proportion in the diet was associated with a quadratic response in $\mathrm{CH}_{4}$ when emissions were expressed per kilogram of FCM or ECM produced. The reduction in ruminal fibrolytic activity (as reflected by in sacco measurements and NDF digestibility) and the decrease in acetate:propionate ratio in cows fed the $100 \%$ CS diet were the main causes of milk fat depression. Lower milk fat concentration has very often been associated with changes in VFA pattern (i.e., lower acetate:propionate ratio) due to disturbance in the ruminal fermentation process (Ruppert et al., 2003; Brito and Broderick, 2006). According to Bauman and Griinari (2001), diets causing a decrease in milk fat content and yield also alter ruminal lipid metabolism, resulting in the formation of specific biohydrogenation intermediates of the trans-10 pathway that directly inhibit milk fat synthesis. Such changes may explain the linear decrease in milk fat content observed when cows were fed increasing proportions of CS in the diet.

Higher milk protein content in cows fed high-starch diets has been related to a greater production of propionate and increased supply of AA (Jenkins and McGuire, 2006), which occurred in the current study as the proportion of CS increased in the diet. The enhanced AA supply is consistent with the decreases in ruminal $\mathrm{NH}_{3}$ concentrations, branched-chain VFA proportions, and protozoa numbers (see the following). The reduction in NDF digestibility resulted in a linear increase $(P<$ $0.01)$ in NDF excreted in manure $(2.96,3.27$, and 3.39 $\mathrm{kg} / \mathrm{d}$ for the 0,50 , and $100 \%$ CS treatments, respectively; data not shown). According to Hindrichsen et al. (2005), the presence of degradable fiber in the manure may contribute to increasing $\mathrm{CH}_{4}$ emissions from stored manure. The effect of increasing the CS proportion in the diet of dairy cows on $\mathrm{CH}_{4}$ emissions from manure storage is yet to be determined.

\section{Effects of Corn Silage on N Balance}

To successfully reduce the environmental impact of dairy production, reductions in enteric $\mathrm{CH}_{4}$ must not be achieved at the expense of higher other undesirable emissions such as $\mathrm{NH}_{3}$ and $\mathrm{N}_{2} \mathrm{O}$. Based on these considerations, in addition to assessing the effect of shifting dietary forage source from AS to $\mathrm{CS}$ on enteric $\mathrm{CH}_{4}$ emissions, we also evaluated the effects on manure $\mathrm{N}$ excretion and $\mathrm{N}$ balance.

Daily $\mathrm{N}$ intake remained unaffected by increasing the proportion of CS in the diet because of the concomitant increase in the soybean meal proportion in the diet and the enhanced DMI. Replacing AS (and corn grain) with CS (and soybean meal) in the diet reduced fecal and urinary $\mathrm{N}$ losses and improved efficiency of dietary $\mathrm{N}$ utilization for milk protein synthesis. The decrease in urinary N losses as CS dietary proportion increased can be related to the decrease in ruminal concentration of $\mathrm{NH}_{3}$. When $\mathrm{NH}_{3}$ concentration in the rumen exceeds microbial uptake, excess $\mathrm{NH}_{3}$ is absorbed through the rumen, transferred to the liver, converted to urea, and excreted in urine (Van Soest, 1994). In agreement with our findings, Brito and Broderick (2006) also reported a decrease in ruminal $\mathrm{NH}_{3}$ concentrations associated with a decrease in urinary $\mathrm{N}$ output when the proportion of CS (and soybean meal) increased in the diet at the expense of AS (and corn grain). Compared with protein from AS, ruminal solubility and degradability of protein from soybean meal is low (NRC, 2001). Therefore, shifting the dietary protein source from AS protein to soybean meal protein as CS proportion increased in the diet may have reduced the supply of RDP in 
the rumen, which resulted in reduced $\mathrm{NH}_{3}$ production. Furthermore, $\mathrm{NH}_{3}$ utilization in the rumen is strongly influenced by carbohydrate availability (Russell et al., 1983). Hristov et al. (2005) suggested that an increased supply of fermentable carbohydrates can decrease $\mathrm{NH}_{3}$ production in the rumen (by reducing the deamination process or enhancing the capture of released AA by ruminal microbes) or increase microbial capture of released $\mathrm{NH}_{3}$ in the rumen.

The improved $\mathrm{N}$ utilization observed in the current study could also be related to the decrease in protozoal populations occurring when the proportion of CS increased in the diet. It is well documented that protozoa engulf and degrade dietary protein and bacteria in the rumen, which increases $\mathrm{NH}_{3}$ concentration, reduces microbial protein synthesis, and consequently has a negative influence on $\mathrm{N}$ efficiency in the rumen (Ivan et al., 1991; Koenig et al., 2000; Oldick and Firkins, 2000). The observed decrease in branched-chain VFA molar proportion is an indication of a decrease in ruminal protein degradation (possibly caused by a change in protein source and a decrease in the numbers of the ruminal protozoa population), which may further explain the decrease in ruminal $\mathrm{NH}_{3}$ concentration. In our study, the genera distribution of protozoal populations revealed a decrease in entodiniomorph and an increase in holotrich subpopulations as dietary CS increased. Such changes have been associated with an increase in duodenal bacterial $\mathrm{N}$ flow, as shown by Ivan et al. (2000). Benchaar et al. (2007) and Hristov and Broderick (1996) also observed an increase in microbial protein duodenal flow when CS replaced AS in the diet of dairy cows.

\section{CONCLUSIONS}

Results from this study show that increasing CS (and soybean meal) at the expense of AS (and corn grain) in dairy cow diets can be an effective means to reduce enteric $\mathrm{CH}_{4}$ emissions. However, $\mathrm{CH}_{4}$ production was not changed by feeding cows the $50 \%$ CS diet (i.e., $28.2 \%$ AS and $28.2 \%$ CS in the TMR), whereas it decreased when cows were offered the $100 \%$ CS diet (i.e., $56 \%$ CS in the TMR). This suggests that a critical dietary concentration of starch is required to alter ruminal methanogenesis. The lower $\mathrm{CH}_{4}$ energy losses in cows fed the highest inclusion rate of CS was the result of the effects of a greater supply of starch that made the rumen environment (i.e., lower ruminal $\mathrm{pH}$ and acetate:propionate ratio) less favorable to methanogens and associated protozoa. The positive changes on $\mathrm{N}$ losses (i.e., lower urinary and fecal N) suggest that the dietary shift in forage source from AS to CS would likely result in lower $\mathrm{NH}_{3}$ and $\mathrm{N}_{2} \mathrm{O}$ emissions. However, the reduction in fiber digestion and the resulting increase in volatile solids content of the manure may lead to increased $\mathrm{CH}_{4}$ emissions from manure storage. The evaluation of the effects of increasing CS proportion in the diet at the expense of $\mathrm{AS}$ on emissions of $\mathrm{CH}_{4}$ from manure is in progress.

\section{ACKNOWLEDGMENTS}

The authors thank the Dairy and Swine Research Centre (Agriculture and Agri-Food Canada, Sherbrooke, QC, Canada) staff, including L. Croteau and P. Warburton (technical support), F. Tremblay (methane measurements), S. Méthot (help with the statistical analyses), and the barn crew (care of the cows). The authors also express their thanks to Y. Leboeuf and M. Gingras (Université Laval, Quebec, QC, Canada) for their technical support. A. Lettat was a recipient of a postdoctoral fellowship from the National Science and Engineering Research Council of Canada (Ottawa, ON, Canada). This study was funded by a grant (Dairy Research Cluster) from Agriculture and Agri-Food Canada (Ottawa, ON, Canada), Dairy Farmers of Canada (Ottawa, ON, Canada), and Canadian Dairy Commission (Ottawa, ON, Canada).

\section{REFERENCES}

Aguerre, M. J., M. A. Wattiaux, J. M. Powell, G. A. Broderick, and C. Arndt. 2011. Effect of forage-to-concentrate ratio in dairy cow diets on emission of methane, carbon dioxide, and ammonia, lactation performance, and manure excretion. J. Dairy Sci. 94:30813093.

AOAC (Association of Official Analytical Chemists). 1990. Official Methods of Analysis. 15th ed. AOAC, Arlington, VA.

Bauman, D. E., and J. M. Griinari. 2001. Regulation and nutritional manipulation of milk fat: Low-fat milk syndrome. Livest. Prod. Sci. $70: 15-29$

Beauchemin, K., T. A. McAllister, and S. McGinn. 2009. Dietary mitigation of enteric methane from cattle. CAB Rev. Perspect. Agric. Vet. Sci. Nutr. Nat. Resour. 35:1-18.

Benchaar, C., F. Hassanat, R. Gervais, P. Y. Chouinard, C. Julien and D. I. Massé. 2013. Effects of increasing amounts of corn dried distillers grains with solubles in dairy cow diets on methane production, ruminal fermentation, digestion, $\mathrm{N}$ balance, and milk production. J. Dairy Sci. 96:2413-2427.

Benchaar, C., H. V. Petit, R. Berthiaume, D. R. Ouellet, J. Chiquette, and P. Y. Chouinard. 2007. Effects of essential oils on digestion, ruminal fermentation, rumen microbial populations, milk production, and milk composition in dairy cows fed alfalfa silage or corn silage. J. Dairy Sci. 90:886-897.

Benchaar, C., C. Pomar, and J. Chiquette. 2001. Evaluation of dietary strategies to reduce methane production in ruminants: A modelling approach. Can. J. Anim. Sci. 81:563-574.

Boadi, D., C. Benchaar, J. Chiquette, and D. Masse. 2004. Mitigation strategies to reduce enteric methane emissions from dairy cows: Update review. Can. J. Anim. Sci. 84:319-335.

Brito, A. F., and G. A. Broderick. 2006. Effect of varying dietary ratios of alfalfa silage to corn silage on production and nitrogen utilization in lactating dairy cows. J. Dairy Sci. 89:3924-3938.

Brossard, L., C. Martin, F. Chaucheyras-Durand, and B. MichaletDoreau. 2004. Protozoa involved in butyric rather than lactic fer- 
mentative pattern during latent acidosis in sheep. Reprod. Nutr. Dev. 44:195-206.

CCAC (Canadian Council on Animal Care). 1993. Guide to the Care and Use of Experimental Animals. Vol. 1. 2nd ed., Ottawa, ON, Canada.

Cerrato-Sánchez, M., S. Calsamiglia, and A. Ferret. 2008. Effect of the magnitude of the decrease of rumen $\mathrm{pH}$ on rumen fermentation in a dual-flow continuous culture system. J. Anim. Sci. 86:378-383.

Dehority, B. A. 1993. Laboratory Manual for Classification and Morphology of Rumen Ciliate Protozoa. CRC Press Inc., Boca Raton, FL.

DuBois, M., K. A. Gilles, J. K. Hamilton, P. A. Rebers, and F. Smith 1956. Colorimetric method for determination of sugars and related substances. Anal. Chem. 28:350-356.

Environment Canada. 2012. National inventory report 1990-2010 Greenhouse gas sources and sinks in Canada. Environment Canada, Ottawa, ON, Canada.

EPA (Environmental Protection Agency). 2012. Inventory of U.S Greenhouse Gas Emissions and Sinks: 1990-2010. US EPA, Washington, DC.

Fahey, G. C., Jr., and L. L. Berger. 1988. Carbohydrate nutrition of ruminants. Pages 269-297 in The Ruminant Animal Digestive Physiology and Nutrition. D. C. Church, ed. Prentice Hall Inc., Englewood Cliffs, NJ.

Finlay, B. J., G. Esteban, K. J. Clarke, A. G. Williams, T. M. Embley, and R. P. Hirt. 1994. Some rumen ciliates have endosymbiotic methanogens. FEMS Microbiol. Lett. 117:157-161.

Fonty, G., J.-P. Jouany, E. Forano, and P. Gouet. 1995. L'écosysteme microbien du réticulo-rumen. Pages 229-347 in Nutrition des Ruminants Domestiques, Ingestion et Digestion. R. Jarrige, Y. Ruckebusch, C. Demarquilly, M. H. Farce, and M. Journet, ed. Institut National de la Recherche Agronomique (INRA), Paris, France.

Franzolin, R., and B. A. Dehority. 1996. Effect of prolonged highconcentrate feeding on ruminal protozoa concentrations. J. Anim. Sci. 74:2803-2809

Hall, M. B., J. P. Jennings, B. A. Lewis, and J. B. Robertson. 2001 Evaluation of starch analysis methods for feed samples. J. Sci. Food Agric. 81:17-21.

Hegarty, R. S. 1999. Reducing rumen methane emissions through elimination of rumen protozoa. Aust. J. Agric. Res. 50:1321-1327.

Hindrichsen, I. K., H.-R. Wettstein, A. Machmüller, B. Jörg, and M. Kreuzer. 2005. Effect of the carbohydrate composition of feed concentrates on methane emission from dairy cows and their slurry Environ. Monit. Assess. 107:329-350.

Hindrichsen, I. K., H.-R. Wettstein, A. Machmüller, C. R. Soliva, K. E Bach Knudsen, J. Madsen, and M. Kreuzer. 2004. Effects of feed carbohydrates with contrasting properties on rumen fermentation and methane release in vitro. Can. J. Anim. Sci. 84:265-276.

Hook, S. E., M. A. Steele, K. S. Northwood, A. D. Wright, and B. W McBride. 2011. Impact of high-concentrate feeding and low ruminal $\mathrm{pH}$ on methanogens and protozoa in the rumen of dairy cows. Microb. Ecol. 62:94-105.

Hoover, W. H. 1986. Chemical factors involved in ruminal fiber digestion. J. Dairy Sci. 69:2755-2766.

Hristov, A. N., and G. A. Broderick. 1996. Synthesis of microbial protein in ruminally cannulated cows fed alfalfa silage, alfalfa hay, or corn silage. J. Dairy Sci. 79:1627-1637.

Hristov, A. N., M. Ivan, L. M. Rode, and T. A. McAllister. 2001. Fermentation characteristics and ruminal ciliate protozoal populations in cattle fed medium- or high-concentrate barley-based diets. J. Anim. Sci. 79:515-524.

Hristov, A. N., J. K. Ropp, K. L. Grandeen, S. Abedi, R. P. Etter, A. Melgar, and A. E. Foley. 2005. Effect of carbohydrate source on ammonia utilization in lactating dairy cows. J. Anim. Sci. 83:408-421.

IPCC (Intergovernmental Panel on Climate Change). 2006. 2006 IPCC Guidelines for National Greenhouse Gas Inventories. Vol. 4. Agriculture, Forestry and Other Land Use. S. Eggleston, L. Buendia, K. Miwa, T. Ngara, and K. Tanabe, ed. Institute for Global Environmental Strategies (IGES), Hayama, Kanagawa, Japan.
Ivan, M., M. Hidiroglou, and H. V. Petit. 1991. Duodenal flow of nitrogen following protozoal inoculation of fauna-free sheep fed a diet supplemented with casein or soybean meal. Can. J. Anim. Sci. 71:793-801.

Ivan, M., L. Neill, R. Forster, R. Alimon, L. M. Rode, and T. Entz. 2000. Effects of Isotricha, Dasytricha, Entodinium, and total fauna on ruminal fermentation and duodenal flow in wethers fed different diets. J. Dairy Sci. 83:776-787.

Jenkins, T. C., and M. A. McGuire. 2006. Major advances in nutrition Impact on milk composition. J. Dairy Sci. 89:1302-1310.

Kaur, R., S. C. Garcia, A. Horadagoda, and W. J. Fulkerson. 2010. Evaluation of rumen probe for continuous monitoring of rumen $\mathrm{pH}$, temperature and pressure. Anim. Prod. Sci. 50:98-104.

Kebreab, E., K. A. Johnson, S. L. Archibeque, D. Pape, and T. Wirth. 2008. Model for estimating enteric methane emissions from United States dairy and feedlot cattle. J. Anim. Sci. 86:2738-2748.

Keunen, J. E., J. C. Plaizier, L. Kyriazakis, T. F. Duffield, T. M. Widowski, M. I. Lindinger, and B. W. McBride. 2002. Effects of a subacute ruminal acidosis model on the diet selection of dairy cows. J. Dairy Sci. 85:3304-3313.

Khafipour, E., D. O. Krause, and J. C. Plaizier. 2009a. Alfalfa pelletinduced subacute ruminal acidosis in dairy cows increases bacterial endotoxin in the rumen without causing inflammation. J. Dairy Sci. 92:1712-1724.

Khafipour, E., D. O. Krause, and J. C. Plaizier. 2009b. A grain-based subacute ruminal acidosis challenge causes translocation of lipopolysaccharide and triggers inflammation. J. Dairy Sci. 92:10601070

Khafipour, E., S. Li, J. C. Plaizier, and D. O. Krause. 2009c. Rumen microbiome composition determined using two nutritional models of subacute ruminal acidosis. Appl. Environ. Microbiol. $75: 7115-7124$

Koenig, K. M., C. J. Newbold, F. M. McIntosh, and L. M. Rode. 2000. Effects of protozoa on bacterial nitrogen recycling in the rumen. J. Anim. Sci. 78:2431-2445.

Lana, R. P., J. B. Russell, and M. E. Van Amburgh. 1998. The role of $\mathrm{pH}$ in regulating ruminal methane and ammonia production. J. Anim. Sci. 76:2190-2196.

Mc Geough, E. J., P. O'Kiely, K. J. Hart, A. P. Moloney, T. M. Boland, and D. A. Kenny. 2010. Methane emissions, feed intake, performance, digestibility, and rumen fermentation of finishing beef cattle offered whole-crop wheat silages differing in grain content. J. Anim. Sci. 88:2703-2716.

McAllister, T. A., and C. J. Newbold. 2008. Redirecting rumen fermentation to reduce methanogenesis. Aust. J. Exp. Agric. 48:7-13.

McDonald, I. 1981. A revised model for the estimation of protein degradability in the rumen. J. Agric. Sci. (Camb.) 96:251-252.

Morgavi, D. P., C. Martin, J.-P. Jouany, and M. J. Ranilla. 2012 Rumen protozoa and methanogenesis: Not a simple cause-effect relationship. Br. J. Nutr. 107:388-397.

Mould, F. L., and E. R. Ørskov. 1983. Manipulation of rumen fluid $\mathrm{pH}$ and its influence on cellulolysis in sacco, dry matter degradation and the ruminal microflora of sheep offered either hay or concentrate. Anim. Feed Sci. Technol. 10:1-14.

Newbold, C. J., B. Lassalas, and J. P. Jouany. 1995. The importance of methanogens associated with ciliate protozoa in ruminal methane production in vitro. Lett. Appl. Microbiol. 21:230-234.

NRC. 2001. Nutrient Requirements of Dairy Cattle. 7th rev. ed. National Academy Press, Washington, DC.

Ogimoto, K., and S. Imai. 1981. Techniques in rumen microbiology. Page 158 in Atlas of Rumen Microbiology. Japan Scientific Societies Press, Tokyo, Japan.

Oldick, B. S., and J. L. Firkins. 2000. Effects of degree of fat saturation on fiber digestion and microbial protein synthesis when diets are fed twelve times daily. J. Anim. Sci. 78:2412-2420.

Plaizier, J. C., J. E. Keunen, J. P. Walton, T. F. Duffield, and B. W. McBride. 2001. Effect of subacute ruminal acidosis on in situ digestion of mixed hay in lactating dairy cows. Can. J. Anim. Sci. 81:421-423. 
Ruppert, L. D., J. K. Drackley, D. R. Bremmer, and J. H. Clark. 2003. Effects of tallow in diets based on corn silage or alfalfa silage on digestion and nutrient use by lactating dairy cows. J. Dairy Sci. 86:593-609.

Russell, J. B., C. J. Sniffen, and P. J. Van Soest. 1983. Effect of carbohydrate limitation on degradation and utilization of casein by mixed rumen bacteria. J. Dairy Sci. 66:763-775.

Taylor, K. A. C. C. 1996. A simple colorimetric assay for muramic acid and lactic acid. Appl. Biochem. Biotechnol. 56:49-58.

Tyrrell, H. F., and J. T. Reid. 1965. Prediction of the energy value of cow's milk. J. Dairy Sci. 48:1215-1223.
Van Soest, P. J. 1994. Nutritional Ecology of the Ruminant. 2nd ed. Cornell Univ. Press, Ithaca, NY.

Van Soest, P. J., J. B. Robertson, and B. A. Lewis. 1991. Methods for dietary fiber, neutral detergent fiber, and nonstarch polysaccharides in relation to animal nutrition. J. Dairy Sci. 74:3583-3597.

Weatherburn, M. 1967. Phenol-hypochlorite reaction for determination of ammonia. Anal. Chem. 28:971-974.

Wolin, M. J., and T. L. Miller. 1988. Microbe-microbe interactions. Pages 343-359 in The Rumen Microbial Ecosystem P. N. Hobson, ed. Elsevier Science Publ. Co., New York, NY. 